\title{
Relationships between Temporal Measurements and Swallowing Impairment in Unilateral Stroke Patients
}

\author{
Ikjae Im $^{\mathrm{a}}$, Myoung-Hwan Ko \\ ${ }^{a}$ Department of Language and Rehabilitation Counseling, Catholic Kwandong University Gangneung, Korea \\ ${ }^{b}$ Department of Physical Medicine and Rehabilitation, Jeonbuk National University Medical School, Jeonju, Korea
}

\author{
Correspondence: Myoung-Hwan Ko, PhD \\ Department of Physical Medicine and \\ Rehabilitation, Jeonbuk National University Medical \\ School, 20 Geonji-ro, Deokjin-gu, Jeonju 54907, \\ Korea \\ Tel.: +82-63-250-1795 \\ Fax: +82-63-254-4145 \\ E-mail: mhko@jbnu.ac.kr
}

Received: October 20, 2020

Revised: November 18, 2020

Accepted: November 18, 2020

This research was supported by a grant of the Korea Health Technology R\&D Project through the Korea Health Industry Development Institute (KHIDI), funded by the Ministry of Health \& Welfare, Republic of Korea (grant number: HI15C1529)

This study was supported by a grant of the JNUBBRI.

This work was supported by the Ministry of Education of the Republic of Korea and the National Research Foundation of Korea (NRF2019S1A5B5A07107056)
Objectives: The primary aim of the present study was to investigate the relationships between temporal measurements and swallowing impairment. The secondary aim was to identify potential relationships among age, lesion side, clinical swallowing outcomes, fiftysix consecutive unilateral patients (mean age $=64.73$ years, $S D=13.45$, left damage $=28$ patients, right damage $=28$ patients) participated in this study. Methods: A videofluoroscopic swallowing study (VFSS) was performed using a single bolus of $5 \mathrm{~mL}$ of thin liquid. All patients completed both a magnetic resonance imaging study and VFSS. VFSS images were evaluated using the Modified Barium Swallowing Impairment Profile (MBSImP). Kinematic aspects of swallowing were characterized according to oral transit duration, pharyngeal transit duration, laryngeal response duration (LRD), and laryngeal closure duration (LCD). Path analyses were utilized to explore the relationships between age, lesion side, temporal measurements, and MBSImP score. Results: The results indicated that advanced age was associated with increased oral swallowing impairment and longer laryngeal response in unilateral stroke patients $(p<.01)$. In addition, longer LRD was significantly associated with increased oral swallowing impairment $(p<.05)$. Longer LRD and shorter LCD were significantly associated with increased pharyngeal swallowing impairment $(p<.01)$. Right hemisphere damage was significantly associated with increased pharyngeal impairment $(p<.01)$. Conclusion: The present study was the first to investigate the relationships between temporal measurements and MBSImP score, and the findings confirmed that swallowing outcomes via VFSS can provide physiologic evidence related to swallowing impairment in unilateral stroke patients. We discuss clinical markers to predict the risk of progression to swallowing impairments that may be useful as targets to effectively manage stroke patients with swallowing impairment.

Keywords: Unilateral, Stroke, Swallowing impairment, Modified Barium Swallowing Impairment Profile (MBSImP)
Swallowing disorders are a well-known complication following stroke, and have been associated with a deviant physiological event (Logemann et al., 1993; Robbins, Levine, Maser, Rosenbek, \& Kempster, 1993). Prior studies indicated that stroke patients are more likely to exhibit a longer laryngeal closure duration (LCD) and more frequently suffer aspiration symptoms than normal healthy adults (Bisch, Logemann, Rademaker, Kahrilas, \& Lazarus, 1994; Power et al., 2009). Furthermore, Kim and McCullough
(2007) reported that stroke patients who exhibited the presence of aspiration had a longer laryngeal response duration (LRD) than non-aspirating stroke patients.

A videofluoroscopic swallowing study (VFSS) is generally accepted as the gold standard for visualization of the physiologic event of swallowing. Recent advances in the temporal measurement of swallowing have allowed for a variety of new techniques to be used in the study of physiological swallowing events (Loge- 
mann et al., 2000; Logemann, Pauloski, Rademaker, \& Kahrilas, 2002). For example, a longer LRD in stroke patients has been associated with a late response in airway protection corresponding to entry of a bolus into the pharynx; a response involving the movement of aryepiglottic cartilage and epiglottis, and hyoid and larynx excursion. As appropriate timing is important for the safety and efficiency of swallowing, a prolonged or delayed swallowing duration may lead to impairment in oropharyngeal swallowing. Therefore, temporal measurement of the process could provide valuable evidence on the cause of swallowing impairment. However, only a few studies have reported on this relationship between temporal measurements and swallowing impairment, and these investigations only observed glottic movement in pharyngeal swallowing (Miyaji et al., 2012; Power et al., 2007). Given the various symptoms of swallowing impairment following stroke, a further approach could be to systemically evaluate oropharyngeal swallowing impairment. In this regard, a Modified Barium Swallowing Impairment Profile (MBSImP) can allow review of the swallowing physiology related to oropharyngeal swallowing impairment (Martin-Harris et al., 2008), and prior studies reported on the validation and standardization of MBSImP for the evaluation of oropharyngeal swallowing impairment (Daniels et al., 2017; Martin-Harris et al., 2008).

The specific lesion side affected in unilateral hemispheric damage could possibly have unique effects on swallowing impairment. Daniels, Foundas, Iglesia, and Sullivan (1996) reported that right hemisphere stroke patients exhibited more severe dysphagia than left hemispheric stroke patients. In addition, Robbins et al. (1993) reported that right hemispheric stroke patients are more likely to have a longer pharyngeal transit duration (PTD) than left hemispheric stroke patients. However, Hamdy et al. (1999) reported detecting bilateral activation in a study using functional brain imaging. Therefore, there are discrepancies in the reported results regarding the hemispheric laterality of the swallowing function, and further exploration of any differences in swallowing outcomes between left and right hemisphere unilateral stroke patients could shed further light on the role of the cerebral hemispheres in swallowing functions (Malandraki, Sutton, Perlman, \& Karampinos, 2010). Given the paucity of information on the relationship between temporal measurements and swallowing impairment, the primary aim of the present study was to investigate the relationship between temporal measurements and swallowing impairment. The secondary aim was to identify potential relationships between the lesion side and swallowing outcomes.

\section{METHODS}

\section{Subjects}

This study was approved by the institutional review board of Jeonbuk National University Hospital, Republic of Korea. All participants provided written informed consent prior to inclusion. The consecutive patients included in this study were part of a large cohort of 396 patients undergoing VFSS because of a chief complaint of dysphagia in the rehabilitation unit. From this full cohort, 56 unilateral stroke patients were identified and included in this study. The inclusion criteria were 1) a single-hemisphere-lesion stroke patient, 2) the presence of a supratentorial lesion, and 3) underwent both a magnetic resonance imaging (MRI) study and VFSS. The exclusion criteria were 1) co-existing neurological or medical disorders known to cause dysphagia, and 2) acute $(<8$ days) and chronic stroke patients ( $>3$ months) because of the interval between the MRI study and VFSS.

\section{VFSS}

Subjects underwent VFSS on a Sonialvision Versa 100I/DAR8000 system (Shimadzu Corp., Kyoto, JPN). The VFSS procedure involved the subjects swallowing a $5 \mathrm{~mL}$ bolus of contrast liquid (viscosity $3 \mathrm{cP}, 30 \mathrm{r} / \mathrm{min}, 25^{\circ} \mathrm{C} \pm 1^{\circ} \mathrm{C}$, Brookfield viscometer, Middleboro, MA, USA), which consisted of a $100 \%$ w/v mixture of water and barium sulfate powder (Solotop HD; Tea Joon Pharm Co. Ltd, Seoul, Korea). Fluoroscopic images were saved digitally as AVI files for later analysis. The mean time period between the stroke and VFSS examination time was 31.77 days $(\mathrm{SD}=22.5)$.

\section{Assessment of swallowing}

Swallowing impairment following stroke was assessed as the total score of the oral impairment (OI) and pharyngeal impairment (PI) components of the MBSImP. Four temporal measurements were used to examine the efficacy and efficiency of swallowing function, the following temporal measurement were defined. 1) 
Table 1. Selected physiologic measurements

\begin{tabular}{|c|c|c|}
\hline Component & Scale & \\
\hline \multicolumn{3}{|l|}{ Modified Barium Swallowing Impairment Profile } \\
\hline \multicolumn{3}{|l|}{ Oral Impairment } \\
\hline 1. Lip closure & $0-4$ & \\
\hline 2. Tongue control & $0-3$ & \\
\hline 4. Bolus transport/lingual motion & $0-4$ & \\
\hline 5. Oral residue & $0-4$ & \\
\hline 6. Initiation of the pharyngeal swallow & $0-4$ & \\
\hline \multicolumn{3}{|l|}{ Pharyngeal Impairment } \\
\hline 7. Soft palate elevation & $0-4$ & \\
\hline 8. Laryngeal elevation & $0-3$ & \\
\hline 9. Anterior hyoid motion & $0-2$ & \\
\hline 10. Epiglottic movement & $0-2$ & \\
\hline 11. Laryngeal vestibule closure & $0-2$ & \\
\hline 12. Pharyngeal stripping wave & $0-2$ & \\
\hline 14. Pharyngoesophageal segment opening & $0-3$ & \\
\hline 15. Tongue base retraction & $0-4$ & \\
\hline 16. Pharyngeal residue & $0-4$ & \\
\hline Temporal measurements & Onset & Offset \\
\hline Oral Transit Duration & $\begin{array}{l}\text { The onset frame depicting the initial forward movement of } \\
\text { the main bolus on the tongue }\end{array}$ & $\begin{array}{l}\text { The offset frame depicting the arrival of the bolus head } \\
\text { at the ramus of the mandible }\end{array}$ \\
\hline Pharyngeal Transit Duration & $\begin{array}{l}\text { The onset frame depicting the arrival of the main bolus head } \\
\text { at the ramus of the mandible }\end{array}$ & $\begin{array}{l}\text { The offset frame depicting the tail of the main bolus } \\
\text { entering the upper esophageal sphincter }\end{array}$ \\
\hline Laryngeal Response Duration & $\begin{array}{l}\text { The onset frame depicting the arrival of the bolus head at } \\
\text { the ramus of the mandible }\end{array}$ & $\begin{array}{l}\text { The offset frame depicting contact between the bolus } \\
\text { head and both the arytenoid cartilage and epiglottis }\end{array}$ \\
\hline Laryngeal Closure Duration & $\begin{array}{l}\text { The onset frame depicting contact of the arytenoid cartilage } \\
\text { and epiglottis }\end{array}$ & $\begin{array}{l}\text { The offset frame depicting the final contact between } \\
\text { the two structures before returning to resting posture }\end{array}$ \\
\hline
\end{tabular}

oral transit duration (OTD), 2) PTD, 3) LRD, and 4) LCD (Table 1).

\section{MBSImP score}

MBSImP ratings for the swallowing components were assigned using a 0 to 4 points scale, in which $0-1$ indicates normal function and higher ratings indicate increasingly severe pharyngeal swallowing impairment (Miyaji et al., 2012). The sub-scores for oral and pharyngeal impairment were calculated as the sum of the each component. As only thin liquid was used for the VFSS, oral component 3 , which is related to chewing and mastication ability, was excluded. In addition, component 13, which is related to pharyngeal contraction ability, was also excluded since the anteriorposterior view was not obtained.

\section{Temporal measurements: OTD, PTD, LRD, and LCD}

The four temporal measurements of OTD, PTD, LRD, and LCD were acquired using Final Cut Pro X (Apple Inc., Cupertino, CA,
USA) software. The measurement criteria for these temporal outcomes followed those described previously (Logemenn et al., 2000; Perlman, Booth, \& Grayhack, 1994; Robbins, Hamilton, Lof, \& Kempster, 1992). For each temporal measurement, duration was assessed as the time in seconds from onset to offset, with two frames being selected to determine the onset and offset of each measurement. The onset and offset criteria for each temporal measurement were defined as follows. OTD: the onset frame depicting the initial forward movement of the main bolus on the tongue, and the offset frame depicting the arrival of the bolus head at the ramus of the mandible. PTD: the onset frame depicting the arrival of the main bolus head at the ramus of the mandible, and the offset frame depicting the tail of the main bolus entering the upper esophageal sphincter. LRD: the onset frame depicting the arrival of the bolus head at the ramus of the mandible, and the offset frame depicting contact between the bolus head and both the arytenoid cartilage and epiglottis. LCD: the onset frame depicting 
contact of the arytenoid cartilage and epiglottis, and the offset frame depicting the final contact between the two structures before returning to resting posture.

\section{Statistical Analysis}

The primary variables describing swallowing performance were two subscores of swallowing impairment and four temporal measurements. The lesion side in the unilateral stroke patients was categorized as right hemisphere damage (RHD) or left hemisphere damage (LHD) according to the MRI results. As age has been reported as an impact factor in swallowing impairment and deviant swallowing duration, age was included as an observed variable in the path analysis. The patient sex and the time interval between the MRI study and VFSS were excluded from the analysis because of a low correlation with the outcome variables. Finally, path analysis was used to determine the pathway according to lesion side, age, the four temporal measurements, and the two swallowing impairments, with two models being designed to categorize the impairment as OI or PI.

A full multivariate regression analysis was performed to identify the true nature of the relationships between the mean MBSImP score and the variables including lesion side, mean age, mean OTD, mean PTD, mean LRD, and mean LCD. The model was designed to take the MBSImP sub-category into consideration. The chi-square value of the model was calculated to confirm the hypotheses-fit, and was found to be $6.66(\mathrm{df}=6)$. In addition, the comparative fit index was .98, the goodness to fit index was .97, and the root mean square error of approximation was .045. These values indicate that it was a good model with an adequate fit by the .35 level of significance of the research model adopts the null hypothesis. Multicollinearity was not detected in the independent variables, with the correlation co-efficient being .31. Statistical analysis was performed using SPSS Statistics v. 21 and AMOS v. 21 (IBM Corp, Armonk, NY, USA).

\section{RESULTS}

\section{Patients, measurement reliability, and homogeneity}

The mean age of the unilateral stroke cohort was 64.73 years $(\mathrm{SD}=13.45$, range $38-89)$, with 28 patients (50\%) having RHD and
Table 2. Patient demographics

\begin{tabular}{lc}
\hline Demographics & Total cohort (N=56) \\
\hline Age (Mean \pm SD) & $64.73 \pm 13.45$ \\
Sex & $27(48.2)$ \\
Male & $29(51.8)$ \\
Female & \\
Stroke type & $36(64.3)$ \\
Ischemic & $20(35.7)$ \\
Hemorrhage & \\
Supratentorial lesion level & $25(44.64)$ \\
Cortical & $8(50)$ \\
Subcortical & $3(5.36)$ \\
Both & \\
Lesion hemisphere & $28(50)$ \\
Left & $28(50)$ \\
Right &
\end{tabular}

Values are presented as number (percentage).

$\mathrm{SD}=$ standard deviation.

28 patients (50\%) having LHD. The mean interval between stroke and VFSS was 31.77 days $(\mathrm{SD}=22.83)$. Table 2 presents the demographics of the stroke patients.

The homogeneity between the LHD and RHD patients was assessed, and the mean age $(t=-1.02, p=.31)$, interval between stroke and VFSS $(t=-.05, p=.96), \operatorname{sex}\left(\chi^{2}=.07, p=.79\right)$, and stroke type $\left(\chi^{2}=1.58, p=.45\right)$ showed similar distributions in both groups.

Intra- and inter-observer reliability was evaluated using intraclass correlation coefficients (ICC), with the intra-observer ICC for repeated analysis of a random selection of $20 \%$ of all the VFSS data being .96 (95\% CI = .96-.99) and the inter-observer ICC being $.93(95 \% \mathrm{CI}=.93-.98)$, showing excellent reliability.

\section{Swallowing outcomes}

The mean OI and PI scores were $6.27(\mathrm{SD}=4.27)$ and 5.50 $(\mathrm{SD}=3.19)$, respectively. The mean OTD was .11s $(\mathrm{SD}=.05)$, the mean PTD was .79s $(\mathrm{SD}=.38)$, the mean $\mathrm{LRD}$ was $.99 \mathrm{~s}(\mathrm{SD}=.85)$, and the mean LCD was .58s $(\mathrm{SD}=.23)$.

\section{Relationships between age, lesion side, temporal measurements, and swallowing impairment}

Advanced age demonstrated a significant relationship with increasing OI score $(r=.45, p<.001)$ and longer PTD $(r=.31, p<.02)$. Longer LRD demonstrated a significant relationship with increas- 
Ikjae Im, et al. • Relationship between Temporal Measurements and MBSImP

ing OI score $(r=.42, p<.001)$. A significant interrelationship between OI and PI was also observed $(r=.78, p=.001$; Table 3$)$.

Relationships between age, lesion side, OTD, PTD, LRD, LCD, and OI

Path analysis was performed to evaluate the relative effects of deviant swallowing duration and oral swallowing impairment. The results demonstrated that advanced age was significantly related to an increased OI score $(\beta=.32$; critical ratio $[\mathrm{CR}]=2.45$; standard error $(\mathrm{SE})=.32 ; p=.014)$. In addition, advanced age had a significant influence on longer $\operatorname{LRD}(\beta=.49 ; \mathrm{CR}=4.18$; $\mathrm{SE}=.49$; $p<.001)$, and longer LRD had a significant influence on increasing OI score $(\beta=.31 ; \mathrm{CR}=2.45 ; \mathrm{SE}=.31 ; p=.014$; Tables 4 and 5$)$. Figure 1 presents the schematic path diagram.

Relationships between age, lesion side, OTD, PTD, LRD, LCD, and PI

The path analysis results demonstrated that advanced age sig-

Table 3. Correlations between temporal measurements and swallowing impairment

\begin{tabular}{lcccccc}
\hline Variable & OTD & PTD & LRD & LCD & Ol & PI \\
\hline OTD & 1 & & & & & \\
PTD & .001 & 1 & & & & \\
LRD & .120 & $.310^{*}$ & 1 & & & \\
LCD & .060 & .196 & .195 & 1 & & \\
OI & -.132 & .239 & $.425^{* *}$ & -.037 & 1 & \\
PI & -.145 & .073 & $.311^{*}$ & -.181 & $.776^{* *}$ & 1 \\
\hline
\end{tabular}

$\mathrm{OTD}=$ oral transit duration; $\mathrm{PTD}=$ pharyngeal transit duration; $\mathrm{LRD}=$ laryngeal response duration; $\mathrm{LCD}=$ laryngeal transit duration; $\mathrm{Ol}=$ oral impairment; $\mathrm{Pl}=$ pharyngeal impairment.

${ }^{*} p<.05,{ }^{* *} p<.01$.

Table 4. Significant impact factors for increased oral swallowing impairment

\begin{tabular}{lccc}
\hline \multirow{2}{*}{ Variable } & \multicolumn{3}{c}{ Path analysis } \\
\cline { 2 - 4 } & $\beta$ & CR & $p$ \\
\hline Age & .319 & 2.454 & $.014^{*}$ \\
Lesion side & -.178 & -1.585 & .113 \\
OTD & -.171 & -1.573 & .116 \\
PTD & .099 & .886 & .376 \\
LRD & .307 & 2.448 & $.014^{*}$ \\
LCD & -.177 & -1.587 & .113
\end{tabular}

$\mathrm{CR}=$ critical ratio; $\mathrm{OTD}=$ oral transit duration; $\mathrm{PTD}=$ pharyngeal transit duration; $\mathrm{LRD}=$ laryngeal response duration; $\mathrm{LCD}=$ laryngeal transit duration . ${ }^{*} p<.05$. nificantly influenced longer $\operatorname{LRD}(\beta=.49 ; \mathrm{CR}=4.18 ; \mathrm{SE}=.49$; $p<.001)$. Longer LRD and shorter LCD had significant influences on increasing PI score (LRD: $\beta=.27 \mathrm{CR}=2.01 ; \mathrm{SE}=.27 ; p=.04$; LCD: $\beta=-.31 ; \mathrm{CR}=-2.79 ; \mathrm{SE}=-.31 ; p=.005)$. RHD had a significant influence on increasing PI score $(\beta=-.32$; $\mathrm{CR}=-2.93$; $\mathrm{SE}=$ $-.32 ; p=.003$; Tables 6 and 7 ). Figure 2 presents the schematic path diagram.

Table 5. The standardized direct, indirect, and total effect factors for increased oral swallowing impairment

\begin{tabular}{lcccc}
\hline $\begin{array}{l}\text { Independent } \\
\text { variable }\end{array}$ & Dependent variable & Total effect & Direct effect & $\begin{array}{c}\text { Indirect } \\
\text { effect }\end{array}$ \\
\hline Age & Oral impairment & .465 & .319 & .146 \\
Lesion side & & -.118 & -.178 & .059 \\
Age & OTD & .016 & .016 & - \\
& PTD & .25 & .25 & - \\
& LRD & .493 & .493 & - \\
Lesion side & LCD & .153 & .153 & - \\
& OTD & -.072 & -.072 & - \\
& PTD & .025 & .025 & - \\
OTD & LRD & .05 & .05 & - \\
PTD & LCD & .191 & .191 & - \\
LRD & Oral impairment & -.171 & -.171 & - \\
LCD & & .099 & .099 & - \\
\hline
\end{tabular}

$\mathrm{OTD}=$ oral transit duration; $\mathrm{PTD}=$ pharyngeal transit duration; $\mathrm{LRD}=$ laryngeal response duration; $\mathrm{LCD}=$ laryngeal transit duration.

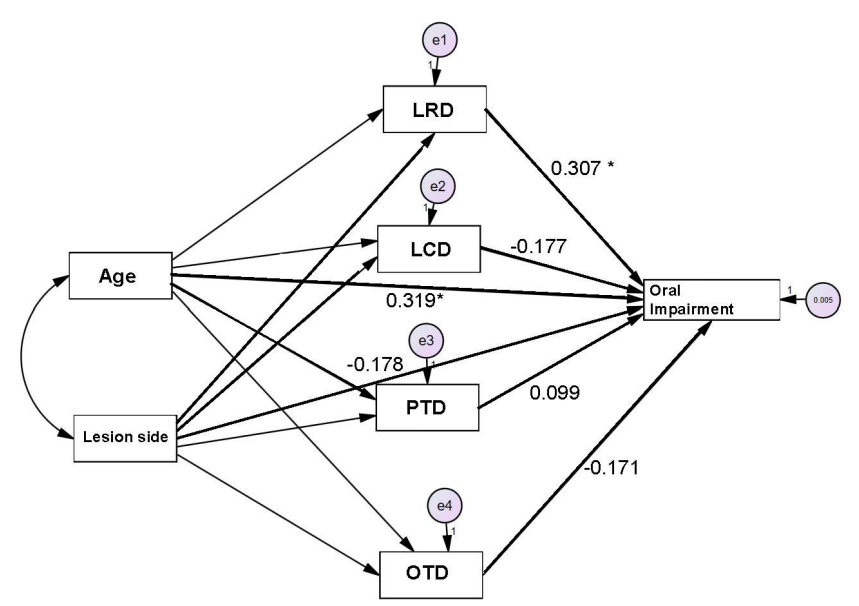

Figure 1. Significant relationships between age, lesion side, temporal measurements, and oral swallowing impairment. OTD= oral transit duration; PTD= pharyngeal transit duration; $\mathrm{LRD}=$ laryngeal response duration; $\mathrm{LCD}=$ laryngeal transit duration. ${ }^{*} p<.05$. 
Table 6. Factors affecting increased pharyngeal swallowing impairment

\begin{tabular}{lcccc}
\hline $\begin{array}{l}\text { Independent } \\
\text { variable }\end{array}$ & Dependent variable & Total effect & Direct effect & $\begin{array}{c}\text { Indirect } \\
\text { effect }\end{array}$ \\
\hline Age & Pharyngeal impairment & .415 & .342 & .073 \\
Lesion side & & -235 & -.322 & .087 \\
Age & OTD & .016 & .016 & - \\
& PTD & .25 & .25 & - \\
& LRD & .493 & .493 & - \\
& LCD & .153 & .153 & - \\
Lesion side & OTD & -.072 & -.072 & - \\
& PTD & -.025 & -.025 & - \\
& LRD & .05 & .05 & - \\
OTD & LCD & -.191 & -.191 & - \\
PTD & Pharyngeal impairment & -.18 & -.18 & - \\
LRD & & -.03 & -.03 & - \\
LCD & & .265 & .265 & - \\
\hline
\end{tabular}

Table 7. The standardized direct, indirect, and total effect factors for increased pharyngeal swallowing impairment

\begin{tabular}{llcl}
\hline \multirow{2}{*}{ Variable } & \multicolumn{3}{c}{ Path analysis } \\
\cline { 2 - 4 } & $\beta$ & CR & $p$ \\
\hline Age & .342 & 2.753 & $.006^{*}$ \\
Lesion side & -.322 & -2.927 & $.003^{* *}$ \\
OTD & -.18 & -1.673 & .094 \\
PTD & -.03 & -.267 & .789 \\
LRD & .265 & 2.064 & $.039^{*}$ \\
LCD & -.312 & -2.787 & $.005^{* *}$ \\
\hline
\end{tabular}

$\mathrm{CR}=$ critical ratio; $\mathrm{OTD}=$ oral transit duration; $\mathrm{PTD}=$ pharyngeal transit duration; $\mathrm{LRD}=$ laryngeal response duration; $\mathrm{LCD}=$ laryngeal transit duration. ${ }^{*} p<.05,{ }^{* *} p<.01$.

\section{DISCUSSION}

The results of the present study indicate that advanced age was associated with increased OI and longer LRD in unilateral stroke patients. In addition, abnormal swallowing durations related to laryngeal events were significantly associated with both increased oral swallowing impairments and increased pharyngeal swallowing impairments. Additionally, RHD demonstrated a significant relationship with increased pharyngeal swallowing impairment.

The results of the present study demonstrate that advanced age is more likely to affect oral swallowing than pharyngeal swallowing. This finding supports the idea that aging has a negative effect on oral function. Prior studies indicated that healthy elderly peo-

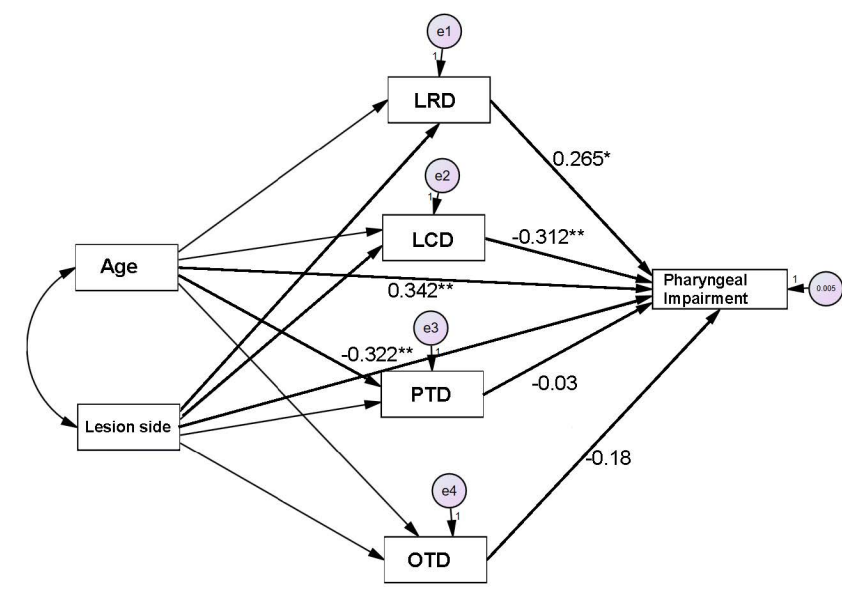

Figure 2. Significant relationships between age, lesion side, temporal measurements, and oral swallowing impairment. OTD= oral transit duration; PTD= pharyngeal transit duration; $\mathrm{LRD}=$ laryngeal response duration; $\mathrm{LCD}=$ laryngeal transit duration. ${ }^{*} p<.05,{ }^{* *} p<.01$.

ple exhibit significantly less tongue strength than healthy younger people, with a significant reduction in tongue strength being exhibited in people over 60 years old (Clark, Henson, Barber, Stierwalt, \& Sherrill, 2003; Nicosia et al., 2000; Youmans, Youmans, \& Stierwalt, 2009). Given the nature of this physiologic change (Boss \& Seegmiller, 1981) advanced age is also likely to be associated with reduced tongue strength in stroke patients, and this may represent a possible reason for oral swallowing impairment. In addition, stroke often causes deteriorations in sensory motor function, which can lead to longer swallowing initiation, decreased pharyngeal transport, and ineffective laryngeal protection (Mann, Hankey, \& Cameron, 1999; Park, Kim, Ko, \& McCullough, 2010; Seo, Oh, \& Han, 2016). In demonstrating that advanced age is significantly associated with longer LRD, the results of the present study are in line with existing knowledge, and are similar to those of the prior investigation by Im, Jun, Hwang and Ko (2018) that showed a significant relationship between advanced age and longer LRD in subcortical stroke patients. Reduced swallowing efficiency in relation to longer swallowing duration has been a subject of discussion for a long time, and at least one reason for premature bolus loss in oropharyngeal swallowing impairment could be a longer LRD, especially with thin liquids (Kim \& McCullough, 2007; Logemann et al., 1992; Park et al., 2010). Premature bolus loss is usually a result of tongue weakness or incoordination of labial muscles and sensory motor dysfunction (Ohmae, Logemann, Kaiser, 
Ikjae Im, et al. • Relationship between Temporal Measurements and MBSImP

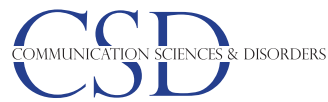

Hanson, \& Kahrilas, 1995; Perlman et al., 1994; Power et al.2009), and on VFSS it is represented by a part of the main bolus entering into the pharynx before the pharyngeal swallowing trigger. Therefore, our finding suggests that elderly stroke patients may be more likely to exhibit reduced sensory motor function, and this could cause a late contact response between the epiglottic petiole and the arytenoids.

In the MBSImP, oral components are utilized to functionally assess lip and tongue control abilities, lingual motion and oral residue, and initiation of the pharyngeal swallow. The pharyngeal components are utilized to assess soft palate and laryngeal elevation, anterior hyoid motion, epiglottic movement, laryngeal vestibule closure, pharyngeal stripping wave, pharyngeal contraction, pharyngeal segment opening, tongue base retraction, and pharyngeal residue (Martin-Harris et al., 2008). Our results demonstrate the strong relationships between longer LRD and both increasing OI and increasing PI scores. Oral component 6 may be particularly reflective of the laryngeal response function related to triggering of pharyngeal swallowing and airway protection. Therefore, our findings suggest that LRD could be closely related to oral component 6 . In addition, we also found a significant relationship between shorter LCD and PI. To evaluate LCD, we focused on observing specific physiological events such as the duration of contact between the epiglottic petiole and the arytenoids, which is the segment of the swallowing process involved in sealing the laryngeal vestibule. We measured the duration from the time of initial contact (onset) to the time of the initial upward movement of the epiglottis (offset); hence, a shorter LCD could represent insufficient laryngeal closure for airway protection, and could result in an increase in the PI score. Abnormal laryngeal closure might be closely related to the laryngeal elevation, anterior hyoid motion, epiglottis movement, and laryngeal vestibule closure, which are pharyngeal components of the MBSImP.

The finding of a significant relationship between RHD and PI is partially supported by prior studies reported laterality in swallowing. It is reported that pharyngeal swallowing impairment is associated with right hemispheric damage (Robbins et al., 1993). Moreover, Im, Kim, Kim and Ko (2017) also reported that right hemisphere stroke patients are more likely to exhibit aspirationpenetration symptoms and longer LRD than are left hemispheric stroke patients. However, functional brain imaging has shown bilateral activation of the sensory motor cortex (Hamdy et al., 1999; Suzuki et al., 2003). To date, the evidence for swallowing laterality is inconclusive. Moreover, in the VFSS in the present study, swallowing was performed using an informed procedure in all cases. For example, the subject could anticipate the procedure because they had been told about the swallowing task procedure, and had been informed that they should swallow the bolus on their tongue according to the physician's or speech language pathologist's verbal cue. Given the neurophysiological difference between voluntary and involuntary swallowing (Martin, Goodyear, Gati, \& Menon, 2001; Mosier et al., 1999), this speculation requires an additional investigation with a different focus, such as an involuntary swallowing task without the patient being consciously aware of the swallowing procedure.

In summary, the results of the present study can provide the basic data to understand the swallowing impairments through path analysis of unilateral stroke patients by examining the interaction process in the dynamic relationship among laterality, age, oral and pharyngeal swallowing impairments and temporal measurements such as, OTD, PTD, LRD, LCD. This investigation may be guide as the primary source to identify factors that could lead to swallowing impairment. Specifically, age might contribute to oral swallowing impairments and delayed pharyngeal reflex was found to have a negative effect on both oral and pharyngeal swallowing impairments.

\section{Limitations}

The present study is subject to several limitations. The time interval between the MRI and VFSS studies varied. It is possible that the severity of stroke and swallowing impairment changed during the lapsed time. In addition, patient handedness was not included in the patient demographics. It is possible that handedness could influence the neural control of swallowing. Further investigation is required for this possibility. Lastly, our stroke cohort was part of a large consecutively admitted group of stroke patients who underwent MRI and VFSS procedures. In the present study, we only analyzed the VFSS data acquired using $5 \mathrm{~mL}$ of thin liquid because this bolus volume and viscosity is well recognized for its ability to detect a change in swallowing physiology (Bisch et al., 1994; Im, Kim, 
Oommen, Kim, \& Ko, 2012; Lee, Yoo, Kim, \& Ryu, 2013). However, to corroborate the presence of a robust relationship between temporal measurement and swallowing impairment, future study should include VFSS with various bolus volumes and viscosities.

\section{Conclusions}

Advanced age and reduced swallowing efficiency are related to laryngeal closure and may contribute to increased oropharyngeal swallowing impairment. Furthermore, RHD may indicate a vulnerability to impairments in pharyngeal swallowing. The present study was the first to investigate the relationships between temporal measurements of the swallowing events and MBSImP score. The findings confirmed that swallowing outcomes via VFSS can provide physiologic evidence related to swallowing impairment in unilateral stroke patients. We discuss clinical markers to predict the risk of progression to swallowing impairments that may be useful as targets to effectively manage stroke patients with swallowing impairments.

\section{REFERENCES}

Bisch, E. M., Logemann, J. A., Rademaker, A. W., Kahrilas, P. J., \& Lazarus, C. L. (1994). Pharyngeal effects of bolus volume, viscosity, and temperature in patients with dysphagia resulting from neurologic impairment and in normal subjects. Journal of Speech, Language, and Hearing Research, 37(5), 1041-1049.

Boss, G. R., \& Seegmiller, J. E. (1981). Age-related physiological changes and their clinical significance. Western Journal of Medicine, 135(6), 434-440

Clark, H. M., Henson, P. A., Barber, W. D., Stierwalt, J. A., \& Sherrill, M. (2003). Relationships among subjective and objective measures of tongue strength and oral phase swallowing impairments. American Journal of Speech-Language Pathology, 12(1), 40-50.

Daniels, S. K., Foundas, A. L., Iglesia, G. C., \& Sullivan, M. A. (1996). Lesion site in unilateral stroke patients with dysphagia. Journal of Stroke and Cerebrovascular Diseases, 6(1), 30-34.

Daniels, S. K., Pathak, S., Mukhi, S. V., Stach, C. B., Morgan, R. O., \& Anderson, J. A. (2017). The relationship between lesion localization and dysphagia in acute stroke. Dysphagia, 32(6), 777-784.

Hamdy, S., Mikulis, D. J., Crawley, A., Xue, S., Lau, H., Henry, S., \& Diamant, N. E. (1999). Cortical activation during human volitional swallowing: an event-related fMRI study. American Journal of Physiology-Gastrointestinal and Liver Physiology, 277(1), G219-G225.

Im, I., Kim, H., Kim, H. G., \& Ko, M. H. (2017). Relationship between temporal measurements of pharyngeal swallowing and penetration-aspiration in unilateral stroke patients. Communication Sciences \& Disorders, 22(3), 570-577.

Im, I., Kim, Y., Oommen, E., Kim, H., \& Ko, M. H. (2012). The effects of bolus consistency in pharyngeal transit duration during normal swallowing. Annals of Rehabilitation Medicine, 36(2), 220-225.

Im, I., Jun, J. P., Hwang, S., \& Ko, M. H. (2018). Swallowing outcomes in patients with subcortical stroke associated with lesions of the caudate nucleus and insula. Journal of International Medical Research, 46(9), 3552-3562.

Kim, Y., \& McCullough, G. H. (2007). Stage transition duration in patients poststroke. Dysphagia, 22(4), 299-305.

Lee, S. I., Yoo, J. Y., Kim, M., \& Ryu, J. S. (2013). Changes of timing variables in swallowing of boluses with different viscosities in patients with dysphagia. Archives of Physical Medicine and Rehabilitation, 94(1), 120-126.

Logemann, J. A., Kahrilas, P. J., Cheng, J. O. A. N., Pauloski, B. R., Gibbons, P. J., Rademaker, A. W., \& Lin, S. G. (1992). Closure mechanisms of laryngeal vestibule during swallow. American Journal of Physiology-Gastrointestinal and Liver Physiology, 262(2), G338-G344.

Logemann, J. A., Pauloski, B. R., Rademaker, A. W., Colangelo, L. A., Kahrilas, P. J., \& Smith, C. H. (2000). Temporal and biomechanical characteristics of oropharyngeal swallow in younger and older men. Journal of Speech, Language, and Hearing Research, 43(5), 1264-1274.

Logemann, J. A., Pauloski, B. R., Rademaker, A. W., \& Kahrilas, P. J. (2002). Oropharyngeal swallow in younger and older women. Journal of Speech, Language, and Hearing Research. 45(3), 434-445.

Logemann, J. A., Shanahan, T., Rademaker, A. W., Kahrilas, P. J., Lazar, R., \& Halper, A. (1993). Oropharyngeal swallowing after stroke in the left basal ganglion/internal capsule. Dysphagia, 8(3), 230-234.

Malandraki, G. A., Sutton, B. P., Perlman, A. L., \& Karampinos, D. C. (2010). Age-related differences in laterality of cortical activations in swallowing. Dysphagia, 25(3), 238-249.

Martin, R. E., Goodyear, B. G., Gati, J. S., \& Menon, R. S. (2001). Cerebral cortical representation of automatic and volitional swallowing in humans. Journal of Neurophysiology, 85(2), 938-950.

Martin-Harris, B., Brodsky, M. B., Michel, Y., Castell, D. O., Schleicher, M., Sandidge, J., ... \& Blair, J. (2008). MBS measurement tool for swallow impairment-MBSImp: establishing a standard. Dysphagia, 23(4), 392-405. 
Ikjae Im, et al. • Relationship between Temporal Measurements and MBSImP

Mann, G., Hankey, G. J., \& Cameron, D. (1999). Swallowing function after stroke: prognosis and prognostic factors at 6 months. Stroke, 30(4), 744-748.

Miyaji, H., Umezaki, T., Adachi, K., Sawatsubashi, M., Kiyohara, H., Inoguchi, T., ... \& Komune, S. (2012). Videofluoroscopic assessment of pharyngeal stage delay reflects pathophysiology after brain infarction. The Laryngoscope, 122(12), 2793-2799.

Mosier, K., Patel, R., Liu, W. C., Kalnin, A., Maldjian, J., \& Baredes, S. (1999). Cortical representation of swallowing in normal adults: functional implications. The Laryngoscope, 109(9), 1417-1423.

Nicosia, M. A., Hind, J. A., Roecker, E. B., Carnes, M., Doyle, J., Dengel, G. A., \& Robbins, J. (2000). Age effects on the temporal evolution of isometric and swallowing pressure. The Journals of Gerontology Series A: Biological Sciences and Medical Sciences, 55(11), M634-M640.

Ohmae, Y., Logemann, J. A., Kaiser, P., Hanson, D. G., \& Kahrilas, P. J. (1995). Timing of glottic closure during normal swallow. Head \& Neck, 17(5), 394-402.

Park, T., Kim, Y., Ko, D. H., \& McCullough, G. (2010). Initiation and duration of laryngeal closure during the pharyngeal swallow in post-stroke patients. Dysphagia, 25(3), 177-182.

Perlman, A. L., Booth, B. M., \& Grayhack, J. P. (1994). Videofluoroscopic predictors of aspiration in patients with oropharyngeal dysphagia. Dysphagia, 9(2), 90-95.
Power, M. L., Hamdy, S., Goulermas, J. Y., Tyrrell, P. J., Turnbull, I., \& Thompson, D. G. (2009). Predicting aspiration after hemispheric stroke from timing measures of oropharyngeal bolus flow and laryngeal closure. Dysphagia, 24(3), 257-264.

Power, M. L., Hamdy, S., Singh, S., Tyrrell, P. J., Turnbull, I., \& Thompson, D. G. (2007). Deglutitive laryngeal closure in stroke patients. Journal of Neurology, Neurosurgery \& Psychiatry, 78(2), 141-146.

Robbins, J., Hamilton, J. W., Lof, G. L., \& Kempster, G. B. (1992). Oropharyngeal swallowing in normal adults of different ages. Gastroenterology, 103(3), 823-829.

Robbins, J., Levine, R. L., Maser, A., Rosenbek, J. C., \& Kempster, G. B. (1993). Swallowing after unilateral stroke of the cerebral cortex. Archives of Physical Medicine and Rehabilitation, 74(12), 1295-1300.

Seo, H. G., Oh, B. M., \& Han, T. R. (2016). Swallowing kinematics and factors associated with laryngeal penetration and aspiration in stroke survivors with dysphagia. Dysphagia, 31(2), 160-168.

Suzuki, M., Asada, Y., Ito, J., Hayashi, K., Inoue, H., \& Kitano, H. (2003). Activation of cerebellum and basal ganglia on volitional swallowing detected by functional magnetic resonance imaging. Dysphagia, 18(2), 71-77.

Youmans, S. R., Youmans, G. L., \& Stierwalt, J. A. (2009). Differences in tongue strength across age and gender: is there a diminished strength reserve?. Dysphagia, 24(1), 57-65. 


\section{국문초록}

\section{대뇌 편측 손상에 의한 뇌졸중 환자의 삼킴 시간과 삼킴 장애와의 연관 관계 \\ 임익재 $\cdot$ 고명환 \\ '가톨릭관동대학교 언어재활상담학과, ${ }^{2 ㅈ ㅓ ㄴ ㅂ ㅜ ㄱ ㄷ ㅐ ㅎ ㅏ ㄱ ㄱ ㅛ ㅇ ㅢ ㄱ ㅘ ㄷ ㅐ ㅎ ㅏ ㄱ ~ ㅈ ㅐ ㅎ ㅘ ㄹ ㅇ ㅢ ㅎ ㅏ ㄱ ㄱ ㅛ ㅅ ㅣ ㄹ ~}$}

배경 및 목적: 본 연구의 목적은 대뇌 편측 손상에 의한 뇌졸중 환자의 삼킴 시간과 삼킴 장애와의 연관 관계를 조사하는 것이었다. 또 한, 손상 위치에 따라 삼킴 기능에서 차이가 있는지를 알아보기 위하여 대뇌 손상 위치와 삼킴 검사 결과 간의 연관 관계도 함께 조사하 였다. 방법: 대상자는 대뇌의 편측만 손상된 뇌졸중 환자 56 명이었다(평균 연령 $=64.73$ 세, $\mathrm{SD}=13.45$ ). 뇌졸중 환자는 모두 자기공명영 상 검사와 비디오투시조영삼킴 검사(Videofluoroscopic swallowing study, VFSS)를 수행하였으며, 삼킴 평가에는 연한 농도의 액체 5 $\mathrm{mL}$ 가 사용되었다. VFSS를 이용한 삼킴 기능 평가에는 수정된 바륨 삼킴 장애 프로파일(Modified Barium Swallowing Impairment Profile, MBSImP)과 삼킴 시간(구강통과시간, 인두통과시간, 후두폐쇄유발시간, 후두폐쇄지속시간)을 측정하였고, 연구 목적을 달성 하기 위하여 두 변수 간 연관 관계를 조사하였다. 이때 삼킴 기능에 영향을 줄 수 있는 병변 위치, 연령 등을 고려하여 경로 분석을 실시 하였고 각 변수들 간의 영향력에 대하여 분석하였다. 결과: 대뇌 편측 뇌졸중 환자는 연령이 증가할 수록 구강 삼킴 장애가 심해지고 후 두폐쇄유발시간이 더 길어지는 것으로 조사되었다 $(p<.01)$. 후두폐쇄유발시간이 길어지면 구강 단계 삼킴 장애에도 영향을 주는 것으 로 나타났다 $(p<.05)$. 또한 후두폐쇄유발시간이 길어지는 것과 후두폐쇄지속시간이 짧아지는 것은 서로 영향을 주는 것으로 조사되었 고 이는 인두 삼킴 장애에도 영향을 주었다 $(p<.01)$. 우뇌 손상은 인두 삼킴 장애와 연관 관계가 있는 것으로 나타났다 $(p<.01)$. 논의 및 결론: 편측 손상 뇌졸중 환자의 삼킴 장애를 예측하기 하기 위한 지표로서 MBSImP와 삼킴 시간 간 연관 관계를 살펴보았고 두 삼킴 결과간 밀접한 연관 관계가 있는 것을 확인하였다.

핵심어: 일측 손상, 뇌졸중, 삼킴 장애, Modified Barium Swallowing Impairment Profile (MBSImP)

본 연구는 보건복지부의 재원으로 한국보건산업진흥원의 보건의료기술연구개발 사업 지원에 의하여 이루어진 것임(과제고유번호: HI15C1529).

이 논문은 전북대학교병원 의생명연구원 기획과제 학술연구비에 의하여 연구되었음.

이 논문은 2019년 대한민국 교육부와한국연구재단의 지원을 받아수행된 연구임(NRF-2019S1A5B5A07107056).

\section{참고문헌}

임익재, 김향희, 김현기, 고명환 (2017). 대뇌 손상 위치에 따른 삼킴 시간과 침습 및 흡인 간의 관계. Communication Sciences \& Disorders, 22(3), 570-577.

\section{ORCID}

임익재(제1저자, 교수 https://orcid.org/0000-0002-3158-1333); 고명환(교신저자, 교수 https://orcid.org/0000-0002-0566-3677) 